\section{Comparison of Silorane and Methacrylate-Based Composites on the Polymerization Heat Generated with Different Light- Curing Units and Dentin Thicknesses}

Ricardo Danil Guiraldo', Simonides Consani², Rafael Leonardo Xediek Consani ${ }^{3}$, Sandrine Bittencourt Berger ${ }^{1}$, Américo Bortolazzo Correr ${ }^{2}$, Mário Alexandre Coelho Sinhoreti ${ }^{2}$, Lourenço Correr-Sobrinho ${ }^{2}$

\author{
'Department of Restorative Dentistry, \\ Dental School, University of North \\ of Paraná, Londrina, PR, Brazil \\ ${ }^{2}$ Department of Restorative \\ Dentistry, Piracicaba Dental \\ School, UNICAMP - University of \\ Campinas, Piracicaba, SP, Brazil \\ ${ }^{3}$ Department of Prosthodontics \\ and Periodontics, Piracicaba Dental \\ School, UNICAMP - University of \\ Campinas, Piracicaba, SP, Brazil
}

Correspondence: Prof. Dr. Ricardo Danil Guiraldo, Rua Marselha, 183, Jardim Piza, 86041-100 Londrina, PR, Brasil. Tel: +55-43-3371-7820. e-mail: rdguiraldo@gmail.com
This study evaluated the temperature variation in the pulp chamber during photoactivation of two restorative composite resins (Filtek P90 silorane-based composite and Heliomolar methacrylate-based composite) with either a quartz-tungsten-halogen (OTH) or lightemitting diodes (LED) light-curing unit (LCU) and using dentin thicknesses (0.5 and 1.0 $\mathrm{mm})$. Standardized cavities $(2 \times 2 \times 2 \mathrm{~mm})$ were prepared in 80 bovine incisors, which were randomly assigned to 8 groups according to the photoactivation method and dentin thickness. Filtek P90 and Heliomolar (both in shade A3) were used with their respective adhesive systems (P90 self-etch primer / P90 adhesive bond and Excite adhesive). All experiments were carried out in a controlled environment $\left(37^{\circ} \mathrm{C}\right)$. The temperature variations $\left({ }^{\circ} \mathrm{C}\right)$ were recorded using a digital thermometer attached to a K-type thermocouple. The results were analyzed statistically by ANOVA and Tukey's test $(\alpha=0.05)$. For composite/ dentin thickness interaction, temperature increase was significantly higher in $0.5 \mathrm{~mm}$ dentin thickness $\left(40.07^{\circ} \mathrm{C}\right)$ compared with $1.0 \mathrm{~mm}$ dentin thickness $\left(39.61^{\circ} \mathrm{C}\right)$ for Filtek P90. For composite/LCU interaction, the temperature increase was significantly higher for Filtek P90 $\left(39.21^{\circ} \mathrm{C}-\mathrm{OTH}\right.$ and $\left.40.47^{\circ} \mathrm{C}-\mathrm{LED}\right)$ compared with Heliomolar $\left(38.40^{\circ} \mathrm{C}-\mathrm{OTH}\right.$ and $39.30^{\circ} \mathrm{C}-\mathrm{LED}$ ). The silorane-based composite promoted higher temperature increase in the pulp chamber than the methacrylate-based composite.
Key Words: silorane-based composite, methacrylate-based composite, temperature increase, dentin thickness.

\section{Introduction}

Dental composite resins formulations have evolved continuously since bisphenol A glycidyl methacrylate (BisGMA) was first introduced to dentistry by Bowen in 1962 (1). Currently, most commercially available composite resins have their common basis in the radical polymerization of methacrylates (2). A few years ago, Silorane, a lowshrinkage, tooth-colored restorative material, as claimed by the manufacturer, 3M ESPE, was introduced to the market. Silorane was so named to indicate a hybrid compound of siloxane and oxirane functional moieties (3). Thus, the exothermic polymerization reaction changed due to change in the composite monomer.

The temperature increase in the pulp chamber arises from the exothermic reaction of polymerization and lightcuring unit (LCU). Among the photoactivation equipaments available in the market, the most traditional ones are those that use conventional quartz tungsten halogen $(\mathrm{OTH})(4,5)$. Thus, QTH requires absorbing filters that reduce the passing of infrared energy to the tooth (6). The efficiency of these filters varies according to the manufacturer and, as a result, the unabsorbed energy can produce heat. Currently, the light-emitting diodes (LED) LCU is widely used. The LED is made from semiconductor materials that define the type of emitted light (7). Each semiconductor material presents a range of energy that determines the spectrum of light emission, characterizing the emitted color (7). Thus, LED was introduced as a viable alternative to OTH (7).

Various factors, including type of LCU (8), chemical composition of the restorative material $(9,10)$, heat conduction properties of composite resins $(10,11)$, restoration thickness $(10,11)$, and dentin thickness (12), may influence the intensity of temperature rise during photoactivation (10). Thus, temperature changes have been studied in dental composite resins in experimental conditions using an elastomer mold, a base of chemically polymerized acrylic resin, bovine dentin slice and thermocouple $(8,12)$ or bovine incisor crowns and thermocouple (13). In an in vivo experiment, Zach and Cohen (14) verified that teeth from Rhesus monkeys submitted to different temperature increases suffered irreversible pulp changes due to the elevation of temperature inside the pulp chamber.

The aim of this in vitro study was to evaluate the temperature increase in the pulp chamber during the 
photoactivation of two composite resins (Heliomolar and Filtek P90) with two LCUs (QTH and LED) and two dentin thicknesses $(0.5$ and $1.0 \mathrm{~mm}$ ). The null hypotheses tested were that there is no difference in the temperature increase between silorane- and methacrylate-based composite resins [1], OTH and LED curing lights [2] or dentin thicknesses [3].

\section{Material and Methods}

Filtek P90 (3M ESPE, St. Paul, MN, USA; shade A3) and Heliomolar (Ivoclar Vivadent, Schaan, Liechtenstein; shade A3) were used with their respective adhesive systems (P90 self-etch primer / P90 adhesive bond and Excite adhesive). Information about the materials used in the study is displayed in Table 1.

The power $(\mathrm{mW})$ of the LCUs used in the study - OTH (XL 2500; 3M/ESPE) and LED (Ultra-Lume 5; Ultradent, South Jordan, UT, USA) - was measured with a power meter (Ophir Optronics Inc, Danvers, MA, USA). The diameter of the tips was measured with a digital caliper (model CD-15C; Mitutoyo, Kanagawa, Japan) to determine the tip area and calculate the total irradiance values $\left(\mathrm{mW} / \mathrm{cm}^{2}\right)$ by dividing the power $(\mathrm{mW})$ by the area $\left(\mathrm{cm}^{2}\right)$. From these data, the energy density was calculated based on the total irradiance by different exposure times of photoactivation (Table 2).

For the experiment, 80 bovine incisor crowns were separated from the roots and partially embedded in polyethylene resin, exposing the buccal surface and the root canal. Cavities were prepared using \#3098 cylindrical diamond burs (KG Sorensen, Barueri, SP, Brazil) in a highspeed handpiece with an air/water spray coolant. The cavity was prepared in the central region of the incisal third of the buccal surface $13 \mathrm{~mm}$ from the cemento-enamel junction, with the following dimensions: $2 \mathrm{~mm}$ depth, $2 \mathrm{~mm}$ mesiodistal extension and $2 \mathrm{~mm}$ cervico-incisal extension. The thickness of the remaining dentin of the axial wall was 0.5 or $1.0 \mathrm{~mm}( \pm 0.1 \mathrm{~mm})$, as verified after testing by sectioning the tooth and measuring with a digital caliper (Mitutoyo).

Temperature changes in the pulp chamber were

Table 1. Information about the composites employed according to the manufacturer

\begin{tabular}{lccc}
\hline Composite & Organic matrix & Filler & Photoinitiator \\
\hline $\begin{array}{l}\text { Filtek P90 } \\
\text { (Batch \# 8BL) }\end{array}$ & Silorane resin & $\begin{array}{c}76 \% \text { by weight } \\
\text { (mean particle size: } 0.47 \mu \mathrm{m}) \\
\text { quarz and yttrium fluoride }\end{array}$ & $\begin{array}{c}\text { CQ, iodonium } \\
\text { salt and } \\
\text { electron } \\
\text { donor }\end{array}$ \\
Heliomolar & Bis-GMA, & 66.7\% by weight & \\
(Batch \# F58116) & $\begin{array}{c}\text { UDA and } \\
\text { decandiol } \\
\text { dimethacrylate }\end{array}$ & $\begin{array}{c}\text { (mean particle size: 0.04- 0.2 } \\
\text { triflicon dioxide, ytterbium }\end{array}$ & CQ \\
\hline
\end{tabular}

UDMA: Urethane dimethacrylate. CQ: Camphorquinone. measured using a K-type thermocouple connected to a digital thermometer (TH 1300; Instrutherm, São Paulo, SP, Brazil) with $0.1{ }^{\circ} \mathrm{C}$ accuracy. When the internal temperature of the hood was stabilized at $37^{\circ} \mathrm{C}$, the thermocouple was inserted in the pulp chamber through the root canal (13) staying in contact with the remaining dentin of the axial wall of the cavity.

For Heliomolar, all specimens were etched with Scotchbond Etching Gel 35\% phosphoric acid (3M ESPE) for $20 \mathrm{~s}$, rinsed with water for $20 \mathrm{~s}$, and water excess was blotted with absorbent paper. Two layers of Excite adhesive system (Ivoclar Vivadent) were applied with photoactivation carried out after placement of the second layer. Then, the composite resin was applied in bulk increment and photoactivated according to Table 2. For Filtek P90, the P90 self-etch primer was applied for $15 \mathrm{~s}$, photoactivated for $10 \mathrm{~s}$, followed by application of P90 adhesive bond and photoactivation for $10 \mathrm{~s}$. Then, the composite resin was applied in bulk increment and photoactivated according to Table 2.

All the measurements were performed in a temperature/ humidity-controlled room, with a constant temperature of $37^{\circ} \mathrm{C}$ and $50 \pm 10 \%$ relative humidity. The maximum temperature measured by thermometer for each composite resin was considered as the temperature increase. One operator prepared all cavities, restorations and temperature measurements. The temperature increase data were subjected to three-way (composite $\mathrm{x}$ dentin thickness $x$ LCU) ANOVA and Tukey's test at 5\% significance level.

\section{Results}

There was no statistically significant difference in the mean values of temperature increase for the combinations composite/LCU/dentin thickness ( $p>0.05)$ and dentin thickness/LCU ( $p>0.05)$.

As shown in Table $3(p<0.05)$, for composite/dentin thickness interaction, the increase of temperature was significantly higher in $0.5 \mathrm{~mm}$ dentin thickness $\left(40.07^{\circ} \mathrm{C}\right)$ compared with $1.0 \mathrm{~mm}$ dentin thickness $\left(39.61^{\circ} \mathrm{C}\right)$ for Filtek P90.

For the composite/LCU interaction, the temperature increase was significantly higher for Filtek P90 $\left(39.21^{\circ} \mathrm{C}-\mathrm{OTH}\right.$ and $40.47^{\circ} \mathrm{C}$ - LED) compared with Heliomolar $\left(38.40^{\circ} \mathrm{C}-\mathrm{OTH}\right.$ and $\left.39.30^{\circ} \mathrm{C}-\mathrm{LED}\right)$, respectively $(\mathrm{p}<0.05)$ (Table 4$)$.

Figure 1 presents the wavelength distributions of the LCUs. For the QTH LCU, a curve centered in the 420 to $500-\mathrm{nm}$ range, with a peak of emission at $484 \mathrm{~nm}$, was observed. For the LED LCU, a narrower curve centered in the 440 to $480 \mathrm{~nm}$ range, 
with an emission peak at $454 \mathrm{~nm}$, and another curve in the ultraviolet range were detected.

\section{Discussion}

The tested null hypotheses were rejected because differences were found in the temperature increase among silorane- and methacrylate-based composite resins [1], light curing units [2] and different dentin thicknesses [3]. External heat applied to the tooth can increase the pulp temperature resulting in irreversible damages (14). The effect of dental composite resin polymerization using different LCUs on the number of living human gingival fibroblasts in a pulp chamber model revealed that the percentage of surviving fibroblasts depended on the chemical composition of dental composite resins rather than on the LCU type (15). However, the activation of the composites by visible light can also contribute to temperature increase inside the pulp chamber, causing damages to the pulp (16).

Different formulations of dental composites materials are currently available on the market in a range of combined monomers, such as TEGDMA (triethyleneglycol dimethacrylate), THFMA (tetrahydrofurfuryl methacrylate), Bis-GMA, UDMA (urethane dimethacrylate) and decandiol dimethacrylate (17), the last 3 monomers being present in Heliomolar. The generation of radical species for the methacrylate cure (such as Heliomolar) is performed by a two-component system consisting of camphorquinone, which is the photoinitiator, and a tertiary amine (2). The Filtek P90 composite is based on siloxanes and oxiranes, which polymerize via a cationic ring-opening reaction. This

Table 2. Characteristics of light curing units (LCU)

\begin{tabular}{lccc}
\hline LCU & $\begin{array}{l}\text { Irradiance } \\
\left(\mathrm{mW} / \mathrm{cm}^{2}\right)\end{array}$ & $\begin{array}{c}\text { Photoactivation } \\
\text { time }(\mathrm{s})\end{array}$ & $\begin{array}{c}\text { Energy density } \\
\left(\mathrm{J} / \mathrm{cm}^{2}\right)\end{array}$ \\
\hline XL 2500 (QTH) & 780 & 40 & 31.2 \\
Ultra-Lume 5 (LED) & 900 & 40 & 36 \\
\hline
\end{tabular}

Table 3. Mean values of the temperature increase $\left({ }^{\circ} \mathrm{C}\right)$ for composite/ dentin thickness interaction

\begin{tabular}{|c|c|c|}
\hline \multirow{2}{*}{ Composite resin } & \multicolumn{2}{|c|}{ Dentin thickness $(\mathrm{mm})$} \\
\hline & 0.5 & 1.0 \\
\hline Filtek P90 & $40.07(0.93)$ a,A & $39.61(0.86)$ a,B \\
\hline Heliomolar & $38.83(0.53) \mathrm{b}, \mathrm{A}$ & $38.88(0.51) \mathrm{b}, \mathrm{A}$ \\
\hline
\end{tabular}

Different lowercase letters in columns and uppercase letters in rows indicate statistically significant difference (Tukey's test, $p<0.05$ ). Standard deviations are given in parentheses. reaction occurs in the oxirane component and is induced by a photochemical event in which camphorquinone, excited by light energy, interacts with iodonium salts and electron donors to produce cations as propagating active centers. According to Miletic et al. (18), Filtek P90 had a different temperature curve with significantly higher temperatures when compared with dimethacrylate-based composites. This fact is confirmed during polymerization of Filtek P90 system in another study (10). This implies that the cationic ring-opening polymerization reaction of Filtek P90 poses a different heat generation pattern (19). Moreover, optical pyrometry studies have shown that cationic ring-opening polymerization of oxiranes is a highly exothermic reaction, with temperatures rising from room temperatures to above $100^{\circ} \mathrm{C}$ in seconds (20). It has also been suggested that the rate of heat generated in a cationic polymerization is directly related to the number of photogenerated initiating species present in the system. For both dentin thicknesses, Filtek P90 promoted the greatest increases in temperature (Table 3). According to Loney and Price (21), thicker dentin can reduce the temperature because of the low thermal conductibility of this substrate. The present study confirmed this assertive (with different dentin thickness) only for Filtek P90, probably by the polymerization reaction to generate

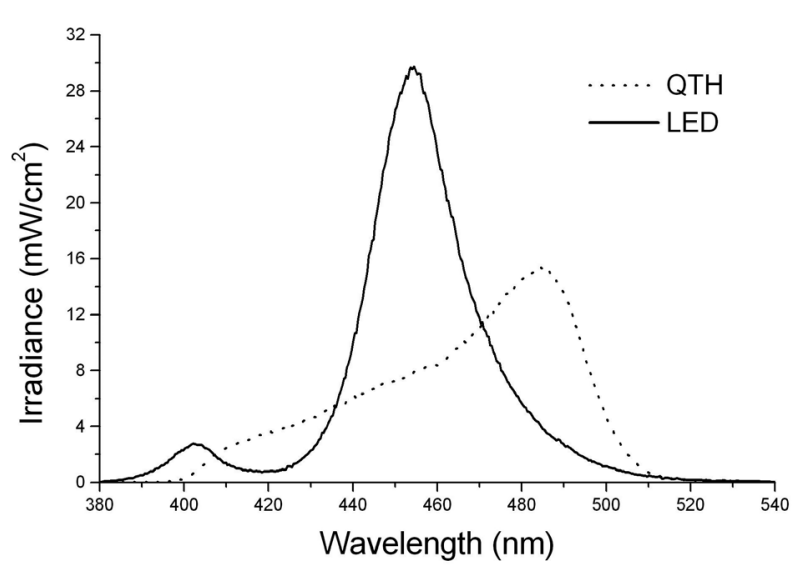

Figure 1. Wavelength distributions of the QTH and LED light-curing units.

Table 4. Mean values of the temperature increase $\left({ }^{\circ} \mathrm{C}\right)$ for composite/ light-curing unit (LCU) interaction

\begin{tabular}{ccc}
\hline \multirow{2}{*}{ Composite resin } & \multicolumn{2}{c}{ LCU } \\
\cline { 2 - 3 } & LED & QTH \\
\hline Filtek P90 & $40.47(0.72) \mathrm{a}, \mathrm{A}$ & $39.21(0.60) \mathrm{a}, \mathrm{B}$ \\
Heliomolar & $39.30(0.24) \mathrm{b}, \mathrm{A}$ & $38.40(0.23) \mathrm{b}, \mathrm{B}$ \\
\hline
\end{tabular}

Different lowercase letters in columns and uppercase letters in rows indicate statistically significant difference (Tukey's test, $p<0.05$ ). Standard deviations are given in parentheses. 
a greater temperature increase (Table 3 ).

As the light energy input during irradiation of both LCUs was the same for the two composite resins, the substantially different pattern of heat generation observed for Filtek P90 may be related to a different polymerization reaction (Table 4). The temperature increase caused by the composite photoactivation resulted from energy density produced by LCUs (22). The conventional LCU with halogen light (XL 2500) used in this study emitted a $31.2 \mathrm{~J} / \mathrm{cm}^{2}$ energy density, considering that the irradiance was 780 $\mathrm{mW} / \mathrm{cm}^{2}$ during $40 \mathrm{~s}$ (energy density $\left(\mathrm{J} / \mathrm{cm}^{2}\right)=$ irradiance $\left(\mathrm{mW} / \mathrm{cm}^{2}\right) \times$ exposure time $\left.(\mathrm{s}) / 1000\right)$ for continuous light modulation. Under similar conditions, the LED unit (UltraLume 5) emitted a $36 \mathrm{~J} / \mathrm{cm}^{2}$ energy density $\left(900 \mathrm{~mW} / \mathrm{cm}^{2}\right.$ for $40 \mathrm{~s})$. For this reason, the temperature increase produced by the LED was significantly higher than the one promoted by QTH in both dental composite resins, probably due to the higher energy density (Table 4). When comparing the spectral profile between the LCUs, LED showed a narrower spectrum of wavelengths and a different peak of emission, while presenting another curve of emission concentrated in the ultraviolet range of the electromagnetic spectrum (23). However, the irradiance level for the effective wavelength region (around $468 \mathrm{~nm}$ ) to activate camphorquinone (photoinitiator present in both composites) was similar for both LCUs (23). Thus, in the present study the spectrum of light seemed to be a secondary factor to the temperature increase.

According to Miletic et al. (18), in vitro studies have limitations that do not allow the re-creation of in vivo mechanisms of heat dissipation such as fluid movement within dentinal tubules, blood or lymphatic circulatory mechanisms, or the cellular and intercellular matrix capacity to absorb heat and thus prevent thermal damage to the living pulp tissue. Even though this study has limitations for being performed in bovine teeth, the results can be considered clinically relevant. According to Zach and Cohen (14), increases of $5.5^{\circ} \mathrm{C}$ would be required to cause irreversible traumas to the pulp. Clinically, even under conditions of high energy density, as promoted by the $\operatorname{LED}\left(36 \mathrm{~J} / \mathrm{cm}^{2}\right)$, and the heat generated by polymerization reaction of Filtek P90 in this study, it is possible that the heat developed does not promote irreversible damage to the pulp because it is below the temperature that could be irreversibly harmful.

Under the experimental conditions of the present study, it may be concluded that higher energy density promotes higher increase of pulp chamber temperature. LED light curing produces higher temperature increase when compared with OTH light curing. Photoactivation of the silorane-based composite promoted higher temperature increase in pulp chamber compared with the methacrylate-based composite.

\section{Resumo}

Este estudo avaliou a variação de temperatura na câmara pulpar durante a fotoativação de duas resinas compostas (Filtek P90 - compósito à base de silorano e Heliomolar - compósito à base de metacrilato) com as unidades foto-ativadoras (UFs) luz de quartzo-tungstênio-halogênio (QTH) ou diodo emissor de luz (LED) e utilizando espessuras de dentina $(0,5$ e $1,0 \mathrm{~mm})$. Cavidades padronizadas $(2 \times 2 \times 2 \mathrm{~mm})$ foram preparadas em 80 incisivos bovinos, as quais foram aleatoriamente divididas em 8 grupos de acordo com os métodos de fotoativação e espessura da dentina. Filtek P90 e Heliomolar (ambos na cor A3) foram utilizadas com seus respectivos sistemas adesivos (Primer P90 auto-condicionante / adesivo P90 e adesivo Excite). Todos os experimentos foram realizados em um ambiente controlado $\left(37^{\circ} \mathrm{C}\right)$. As variações de temperatura $\left({ }^{\circ} \mathrm{C}\right)$ foram mensuradas usando um termômetro digital conectado a um termopar tipo-K. Os resultados foram analisados estatisticamente por ANOVA e teste de Tukey $(\alpha=0,05)$. Para interação compósito/espessura de dentina, o aumento da temperatura foi estatisticamente superior para a espessura de dentina de $0,5 \mathrm{~mm}\left(40,07^{\circ} \mathrm{C}\right)$ quando comparado com a espessura de dentina de $1,0 \mathrm{~mm}\left(39,61^{\circ} \mathrm{C}\right)$ para a Filtek P90. Para a interação compósito/UFs, o aumento de temperatura foi estatisticamente superior para o Filtek P90 $\left(39,21^{\circ} \mathrm{C}-\mathrm{OTH}\right.$ e $40,47^{\circ} \mathrm{C}$ - LED) quando comparado ao Heliomolar $\left(38,40^{\circ} \mathrm{C}-\mathrm{QTH}\right.$ e $39,30^{\circ} \mathrm{C}-$ LED). Compósitos à base de silorano promovem maior aumento da temperatura na câmara pulpar em relação aos compósitos à base de metacrilato.

\section{Acknowledgements}

The authors wish to thank Engineer Marcos Blanco Cangiani for his assistance in methodology.

\section{References}

1. Bowen RL. Dental filling material comprising vinyl-silane treated fused silica and a binder consisting of the reaction product of bisphenol and glycidyl methacrylate. US Patent 3,066,112;1962.

2. Weinmann $W$, Thalacher $C$, Guggenberger R. Siloranes in dental composites. Dent Mater 2005;21:68-78.

3. Navarra CO, Cadenaro M, Armstrong SR, Jessop J, Antoniolli F, Sergo

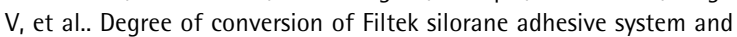
Clearfil SE Bond within the hybrid and adhesive layer: an in situ Raman analysis. Dent Mater 2009;25:1178-1185.

4. Guiraldo RD, Consani S, Consani RL, Berger SB, Mendes WB, Sinhoreti MA. Light energy transmission through composite influenced by material shades. Bull Tokyo Dent Coll 2009;50:183-190.

5. Guiraldo RD, Consani S, Consani RL, Berger SB, Mendes WB, Sinhoreti $M A$, et al.. Comparison of silorane and methacrylate-based composite resins on the curing light transmission. Braz Dent J 2010;21:538-542.

6. Rueggeberg FA. Contemporary issues in photocuring. Compend Contin Educ Dent Suppl 1999;20:S4-S15.

7. Segreto D, Brandt WC, Correr-Sobrinho L, Sinhoreti MA, Consani S. Influence of irradiance on the push-out bond strength of composite restorations photoactivated by LED. J Contemp Dent Pract 2008;9:8996.

8. Guiraldo RD, Consani S, Lympius T, Schneider LF, Sinhoreti MA, CorrerSobrinho L. Influence of the light curing unit and thickness of residual dentin on generation of heat during composite photoactivation. J Oral Sci 2008;50:137-142.

9. Knezević A, Tarle Z, Meniga A, Sutalo J, Pichler G, Ristić M. Degree of conversion and temperature rise during polymerization of composite resin samples with blue diodes. J Oral Rehabil 2001;28:586-591.

10. Mousavinasab SM, Khoroushi M, Moharreri M. Temperature rise during primer, adhesive, and composite resin photopolymerization of a lowshrinkage composite resin under caries-like dentin lesions. ISRN Dent 2012 [Epub ahead of print. DOI: 10.5402/2012/198351].

11. Schneider $L F$, Consani $S$, Correr-Sobrinho $L$, Correr $A B$, Sinhoreti MA. 
Halogen and LED light curing of composite: temperature increase and Knoop hardness. Clin Oral Investig 2006;10:66-71.

12. Guiraldo RD, Consani $S$, De Souza AS, Consani RL, Sinhoreti MA, Correr-Sobrinho L. Influence of light energy density on heat generation during photoactivation of dental composites with different dentin and composite thickness. J Appl Oral Sci 2009;17:289-293.

13. Guiraldo RD, Consani S, Sinhoreti MA, Correr-Sobrinho L, Schneider LF. Thermal variations in the pulp chamber associated with composite insertion techniques and light-curing methods. J Contemp Dent Pract 2009;10:17-24.

14. Zach $\mathrm{L}$, Cohen G. Pulp response to externally applied heat. Oral Surg Oral Med Oral Pathol 1965;19:515-530.

15. Uhl A, Volpel A, Sigusch BW. Influence of heat from light curing units and dental composite polymerization on cells in vitro. J Dent 2006;34:298-306.

16. Masutani S, Setcos JC, Schinell RJ, Philips RW. Temperature rise during polymerization of visible light-activated composite resins. Dent Mater 1988;4:174-178.

17. Lopes MB, Saquy PC, Moura SK, Wang L, Graciano FM, Correr Sobrinho $L$, et al.. Effect of different surface penetrating sealants on the roughness of a nanofiller composite resin. Braz Dent J 2012;23:692697.

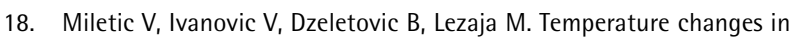
silorane-, ormocer-, and dimethacrylate-based composites and pulp chamber roof during light-curing. J Esthet Restor Dent 2009;21:122131.

19. Gao BT, Lin H, Zheng G, Xu YX, Yang JL. Comparison between a siloranebased composite and methacrylate-based composites: shrinkage characteristics, thermal properties, gel point and vitrification point. Dent Mater J 2012;31:76-85.

20. Crivello J, Falk B, Zonca MR Jr. Photoinduced cationic ring-opening frontal polymerizations of oxetanes and oxiranes. J Polym Sci 2004;42:1630-1646.

21. Loney RW, Price RB. Temperature transmission of high-output light curing units through dentin. Oper Dent 2001;26:516-520.

22. Guiraldo RD, Consani $S$, Mastrofrancisco S, Consani RL, Sinhoreti MA, Correr-Sobrinho L. Influence of light curing unit and ceramic thickness on temperature rise during resin cement photo-activation. Bull Tokyo Dent Coll 2008;49:173-178.

23. Pazin MC, Moraes RR, Gonçalves LS, Borges GA, Sinhoreti MA, CorrerSobrinho L. Effects of ceramic thickness and curing unit on light transmission through leucite-reinforced material and polymerization of dual-cured luting agent. J Oral Sci 2008;50:131-136.

Received November 29, 2011

Accepted April 26, 2013 